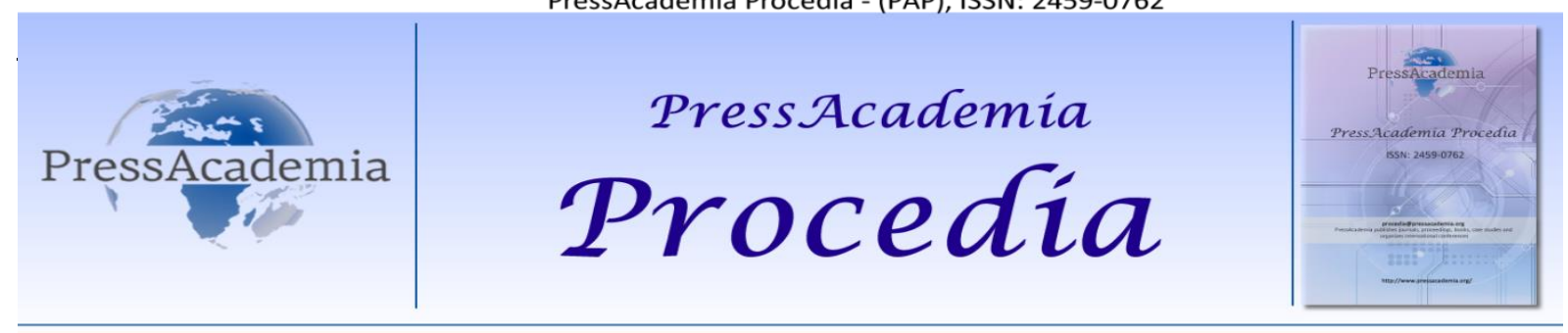

Global Business Research Congress (GBRC), May 24-25, 2017, Istanbul, Turkey.

\title{
THE EFFECT OF HOPELESSNESS LEVELS ON SECTORAL ATTITUDES OF THE TOURISM STUDENTS: SAMPLE OF SELCUK UNIVERSITY BEYSEHIR ALI AKKANAT FACULTY OF TOURISM AND VOCATIONAL SCHOOL
}

DOI: 10.17261/Pressacademia.2017.392

PAP-GBRC-V.3-2017(7)-p.58-67

Adnan Celik ${ }^{1}$, Tahir Akgemci ${ }^{2}$ Emine Vasfiye Korkmaz ${ }^{3}$

${ }^{1}$ Selçuk Üniversitesi, i.i.B.F. Konya, Türkiye, adnancelik@selcuk.edu.tr

${ }^{2}$ Selçuk Ünviversitesi. i.i.i.B.F. Konya, Türkiye, takgemci@selcuk.edu.tr

${ }^{3}$ Selçuk Ünviversitesi. Beyşehir Ali Akkanat Iş̧letme Fakültesi, Konya, Türkiye, eminekorkmaz@selcuk.edu.tr

To cite this document

Celik A., T. Akgemci and E.V.Korkmaz, (2017). The effect of hopelenessness levels on sectorial attitudes of the tourism students: sample of Selcuk University Beysehir Ali Akkanat faculty of tourism and vocational school. PressAcademia Procedia (PAP), V.3, p.58-67.

Permemant link to this document: $\mathrm{http}: / /$ doi.org/10.17261/Pressacademia.2017.392

Copyright: Published by PressAcademia and limited licenced re-use rights only.

\begin{abstract}
This study has been made to determine the effects of hopelessness levels on sectoral attitudes of the students having tourism education at universities. In accordance with this purpose, theoretical part of the study has been made from the literature related with the subject. The study has a quality of empirical research. The study has a quality of empirical research. In the study, survey technique is used as data collecting instrument. In the context of this study, we administered a structured survey to students in Selçuk University Beyşehir Ali Akkanat Faculty of Tourism and Vocational School. The data obtained in this study will be analyzed by the programme of SPSS23. It is considered that the findings to be obtained at the end of the study will make contribution to eliminating the deficiency in the area and will present useful opinions toward the literature and application.
\end{abstract}

Keywords: Hopelenessness, career management, tourism, education, students.

JEL Codes: M10, M12, Z32

\section{TURIZM ÖĞRENCILERININ UMUTSUZLUK DÜZEYLERININ SEKTÖREL TUTUMLARINA ETKISI, SELÇUK ÜNIVERSITESI BEYŞEHIR ALI AKKANAT IŞLETME FAKÜLTESI ÖRNEĞi}

\section{ÖZET}

$\mathrm{Bu}$ araştırma, üniversitede turizm eğitimi alan öğrencilerin umutsuzluk düzeylerinin sektörel tutumlarına etkisini belirlemek amacıyla yapılmıştır. Bu amaç doğrultusunda konuyla ilgili literatürden araştırmanın teorik kısmı hazırlanmıştır. Çalışma ampirik bir araştırma niteliğindedir. Araştırmada veri toplama aracı olarak anket tekniği kullanılmaktadır. Araştırma kapsamında Selçuk Üniversitesi Beyşehir Ali Akkanat Turizm Fakültesi ve MYO'daki öğrencilere anket uygulanmıştır. Bu çalışmada elde edilen veriler SPSS23 programı ile analiz edilecektir. Çalışma sonucunda elde edilecek bulguların alandaki eksikliğin giderilmesine katkı sağlayacağı, yazına ve pratik uygulamaya yönelik yararlı fikirler sunacağı düşünülmektedir.

Anahtar Kelimeler: Umutsuzluk, kariyer yönetimi, turizm, eğitim, öğrenci.

JEL Kodları: M10, M12, Z32 


\section{GiRiş}

Umut, bireyin zor ve stresli durumlarla başa çıkmasını sağlayan en değerli kaynaktır. Bireyi motive ederek gerektiğinde birçok şeye ulaşmasına olanak tanıyan bir güçtür. Umut ve umutsuzluk karşıt beklentileri simgeler. Umutta, amaca ulaşma, başarılı olma beklentisi varken, umutsuzlukta olumsuz sonuç beklentisi vardır. Kişi hoşlanmadığı deneyimler karşısında umutsuzluk yaşayabilir (Aktaran: Kargın ve Ünal, 2011:55).

Üniversite öğrenimi, kişisel, sosyal, mesleki ve ekonomik pek çok sorunla başa çıkmayı gerektiren bir geçiş dönemidir. Üniversite öğrencilerinin bu süreçte karşı karşıya gelebildikleri sorunlardan biri umutsuzluktur. Öğrencilerin üniversite eğitimi sırasında yaşadıkları ekonomik güçlükler, kariyerleriyle ilgili algıladıkları sorunlar ve sosyal ilişki ağları gibi pek çok değişken öğrencilerin umutsuzluk düzeylerini etkileyebilmektedir (Baş ve Kabasakal, 2013:19).

Bu araştırma, üniversitede turizm eğitimi alan öğrencilerin umutsuzluk düzeylerinin sektörel tutumlarına etkisini belirlemek amacıyla yapılmıştır.

\section{LITERATÜR INCELEMESi}

\subsection{Umutsuzluk}

Umutsuzluğun varoluş nedeni umudun yokluğudur. Bu bağlamda umutsuzluğun anlaşılabilmesi için öncelikli olarak umudun tanımlanması gerekir. Umut kısaca "iyi olma duygusu veren ve kişiyi harekete geçirmek için güdüleyen bir özellik" olarak tanımlanmaktadır (Aktaran: Tercanlı ve Demir, 2012:29).

Türkçede umut yerine kullanılan ümit kelimesi Arapça ,ümmîd kelimesinden gelmektedir. Psikologlara göre umut, gelecek ile ilgili bir amacı gerçekleştirmede sıfırdan fazla olan beklentilerdir. Fromm'a göre umut, daha büyük bir canlılık, daha yüksek bir duyarlılık ve akılcılık sağlamak yönünde gerçekleştirilmek istenen her toplumsal değişimin belirleyici öğesidir. Frankl ise "yaşama iradesi" ni umut karşılığı olarak kullanmaktadır (Aktaran: İmamoğlu ve Yavuz, 2011:212).

Umutsuzluk, depresyon sendromunun bir bilişsel bileşenidir ve gelecekle ilgili negatif beklentileri ve duyguları içerir. Beck ve arkadaşları, umutsuzluğu, çevresel stresle aktifleşmiş nispeten bir beklenti kümesi olarak görmektedirler. Umutsuzluk, bireylerin hataların üstesinden gelemeyeceklerini düşünmelerine neden olabilir (Aktaran: Ilgaz, 2011:64).

Ceyhan'a göre "umutsuzluk ve umutsuzluğa bağlı olarak depresyon geliştiren bireyler, isteksizlik, güçsüzlük, güdülenme eksikliği, karamsarlık, dikkatini verememe, yaşamında düzensizlikler gibi belirtiler sergileyebilirler". Türkiye "de ve yurt dışında da gençlerin umutsuzluk düzeyleri farklı değişkenlere göre araştırılmıştır. Özmen ve arkadaşları "Yaşanan sosyal ve ekonomik sorunlar, işsizlik, üniversiteye giriş ve eğitim sorunları ergenlerin ruhsal gelişimlerini ve ruh sağlıklarını olumsuz yönde etkilemektedir" sonucuna ulaşmışlardır (Aktaran: Aras, 2011:512).

Hawthorne deneylerinde, verimli çalışmanın kaynağını mutlu çalışanın oluşturduğu kabul görmektedir. Mutluluğun kaynağını ise çalışanların umut düzeylerinin yüksekliğine karşı kaygı düzeylerinin düşüklüğü ile açıklanmaktadır (Aktaran: Üngüren ve Ehtiyar, 2009: 2097).

Ülkemizde sosyal ve ekonomik boyutta yaşanan sıkıntılar, eğitim alanındaki eksiklikler ve geleceğe dair kaygılar gençlerimizin psikolojik durumlarını olumsuz etkilemekte ve onlarda geleceğe yönelik umutsuzluk duygusunu oluşturmaktadır (Özmen, Dündar, Çetinkaya, Taşkın ve Özmen, 2008).

Öğrencilerin umutsuzluk düzeylerinin belirlenmesi ve yüksek çıkan umutsuzluk düzeyleri varsa buna sebep olan durumların giderilmesi gelece dair daha umutlu ve verimli bireylere sahip olma adına önemlidir.

\subsection{Türkiye'de Turizm Eğitimi Alan Öğrencilerin Sektöre Yönelik Tutumları}

Turizm; yabancıların sürekli yerleşmemek ve gelir elde etmemek koşuluyla seyahat ve geçici konaklamalarından kaynaklanan olaylar ve ilişkiler bütünüdür (Aktaran: Bayer, 1998:145).

Sektörünün yapısı gereği üretim ve tüketimin eş zamanlı olmasından dolayı insan unsuru ön plana çıkmaktadır. İnsan unsurunun ön plana çıktığı bu sektörde hizmet kalitesinin arttırılması ancak nitelikli personel ile mümkün olduğundan turizm işletmelerinin, sektörün ana unsuru olan insan faktörüne dikkat etmeleri gerekmektedir (Orhan, 2015:1). Bu yüzden sektörde yer alacak personelin en iyi şekilde eğitilmesi sektörün verimliliği ve başarısı açısından önem arzetmektedir.

Türkiye'deki turizm eğitimi faaliyetleri, 1953 yılında Ankara ve İzmir Ticaret Liselerinde turizm meslek kurslarının açılması ve bazı turizm derneklerinin de tercüman rehberlik kurslarını düzenlemeleri ile devam etmiştir. Yine, İstanbul'da 1955 yılında ve İzmir'de 1960 yılında turist rehberliği kursları açılıışır. Bunların yanında, "7334 Sayılı Iktisadi ve Ticari ilimler Akademileri Kanunu" gereğince bir ihtisas kolu olarak turizm bölümlerinin kurulması ve 1961-62 öğretim yılında Ankara Otelcilik Okulu'nun açılması, planlı dönemin hazırlık safhasında gerçekleşen gelişmelerdir (Aktaran: Boylu ve Arslan: 2014). 
Günümüzde Türkiye'de mesleki turizm eğitiminin; örgün turizm eğitimi ve yaygın turizm eğitimi olmak üzere iki şekilde gerçekleştiği bilinmektedir. Örgün turizm eğitimi, Milli Eğitim Bakanlığı'na bağlı liseler ve Yüksek Öğretim Kurulu'na bağlı üniversitelerce yürütülür. Turizm otelcilik liseleri, ön lisans, lisans ve lisansüstü olarak verilen mesleki eğitim genel olarak örgün eğitim olarak adlandırımaktadır. Yaygın turizm eğitimi ise, gerek resmi gerekse özel kurumlar tarafından verilen, sertifikaya dayalı kısa süreli mesleki kursları ifade etmektedir (Yağcı, 2001:25).

Turizm eğitiminde öğrencilerin tutumlarını belirlemeye yönelik araştırmalar, durum belirleyici ve bilgi saptayıcı kaynaklar olarak değerlendirilmekte ve turizm sektörü için önemli sosyolojik araştırmalar olarak görülmektedir. Türkiye'de turizm eğitimine yönelik son dönem sosyolojik araştırmalar incelendiğinde istihdam, sektörel beklenti, sektörel kaygı ve staj uygulamalarına yönelik araştırmalara sıkça rastlanmaktadır (Aktaran: Ayaz, Yeşiltaş ve Türkmen, 2012:104).

Ülkemizde turizm eğitimi veren okul sayıları daha çok yükseköğretim düzeyinde yoğunlaşması bazı sorunları gündeme getirmektedir. Avrupa Birliği'ndeki ülkelerin mevcut turizm eğitimi veren kurumları incelendiğinde genelde kurslar ve ortaöğrenim düzeyinde yoğunlaşmakta olduğu görülür (Ehtiyar ve Üngüren, 2008:161). Aşağıda yer alan Tablo 1'de turizm eğitimi almakta olanlar veya turizm eğitimi almakta olanlar üzerine yapılan araştırmalar özet halde sunulmuştur:

Tablo 1: Turizm Eğitimi Almakta Olanlar veya Turizm Eğitimi Almakta Olanlar Üzerine Yapılan Araştırmalar

\begin{tabular}{|c|c|}
\hline Yazar/Yazarlar & Temel Bulgu \\
\hline $\begin{array}{l}\text { Kızılırmak (2000), Kuşluvan (2000), Ağaoğlu (1991), Tüylüoğlu } \\
\text { (2003), King ve arkadaşları (2003), Altman ve Brothers (1995) Tu }\end{array}$ & $\begin{array}{l}\text { Turizm sektörünün işgücü ihtiyacını, turizm eğitimi almamış } \\
\text { işgücünü istihdam ederek karşılamakta olduğu tespit edilmiştir. } \\
\text { Ayrıca turizm eğitimi almış mezunların büyük çoğunluğunun } \\
\text { turizm sektörü dışında istihdam edildiği saptanmıştır. }\end{array}$ \\
\hline Ünlüönen (2004), Kuşluvan ve Kuşluvan (2000) & $\begin{array}{l}\text { Öğrencilerin okumakta oldukları programa ve mezuniyet sonrası } \\
\text { iş imkânları ile ilgili değerlendirmelerinde zamanla olumsuz } \\
\text { yönde değişimler saptanmıştır. Ayrıca araştırmaya katılan } \\
\text { öğrencilerin çoğunluğunun seçtiği bölümden pişman oldukları } \\
\text { ifade edilmiştir. }\end{array}$ \\
\hline Aksu ve Köksal (2005) & $\begin{array}{l}\text { Öğrencilerin sektöre karşı olumsuz bir tutum ve görüş içerisinde } \\
\text { oldukları saptanmıştır. Çoğunlukla olumsuz tutum ve görüş } \\
\text { içerisinde olan öğrencilerin yanında olumlu görüş beyan eden } \\
\text { öğrenciler de bulunmuş, bu öğrencilerin üniversite giriş } \\
\text { sınavında turizm bölümünü ilk sırada ve istekli seçtikleri, } \\
\text { stajlarını yurt dışında gerçekleştirdikleri belirtilmiştir. }\end{array}$ \\
\hline Güzel (2006), Aktaş ve Boyacı (1992 & $\begin{array}{l}\text { Yükseköğretim kurumlarında sunulan turizm eğitiminin hizmet } \\
\text { kalitesi bakımından öğrencilerin beklentilerini karşılamadıklarını } \\
\text { ve tatmin düzeylerinin oldukça düşük olduğu tespit edilmiştir. }\end{array}$ \\
\hline $\begin{array}{l}\text { Pelit ve Güçer (2006), Gökdeniz ve ark. (2002), Çakır (1998), } \\
\text { Kuşluvan ve Kuşluvan (2000), Baron ve Maxwell (1993) }\end{array}$ & $\begin{array}{l}\text { Öğrenciler, verilen eğitimin staj esnasında yarar sağlamadığını } \\
\text { belirtmiş ve staj yaptıkları kurumlarının kendilerini ucuz iş gücü } \\
\text { olarak gördükleri ifade edilmiştir. Ayrıca öğrencilerin stajlardan } \\
\text { memnun olmadıkları ve stajın öğrencileri meslekten } \\
\text { uzaklaştırdığı saptanmıştır. }\end{array}$ \\
\hline Üzümcü ve Bayraktar (2004) & $\begin{array}{l}\text { Turizm eğitmenlerinin verdiği mesleki eğitimi etik açısından } \\
\text { inceledikleri araştırmada, etik ilkelerin tam olarak } \\
\text { uygulanmadığını ve verilen eğitimin yetersiz olduğunu } \\
\text { saptamışlardır. }\end{array}$ \\
\hline
\end{tabular}

Kaynak: Ehtiyar ve Üngüren, 2008:161

Bu sonuçlar göstermektedir ki turizm eğitim alanında çözülmesi gereken ciddi konular vardır. Türkiye'ye daha kaliteli turist çekmek için turizm eğitiminin önemi ve bu konu ile alakalı çözüm yöntemleri geliştirilmelidir. Sektörde müşteri ile yüz yüze hizmet sunan çalışanların hizmet kalitesi artıkça, hizmeti tekrar tercih etmeye gönüllü müşteri sayısı da artacaktır. Bu sebeple turizm sektöründe bir marka haline gelebilmenin temel şartı hizmetin kalitesine ve bu hizmeti sunan çalışanın motivasyonuna bağlı olduğu unutulmamalıdır.

Bu çalışmanın amacı, ülke ekonomisine önemli destek sağlayan turizm sektöründeki hizmetleri sunmak üzere yetiştirilen turizm öğrencilerinin, umutsuzluk düzeylerinin sektöre karşı tutumları ile olan etkileşimini ortaya koymaktır. 


\section{VERI VE YÖNTEM}

\subsection{Araştırmanın Kapsamı, Önemi, Sınırlııkları}

Turizm sektörünün hizmete dayalı bir sektör olması, verilen hizmet kalitesinin diğer sektörlere göre örgütün başarısının artması açısından önemli olmasına neden olmaktadır. Hizmeti sunacak olan çalışanın eğitilmesi, geliştirilmesi, motivasyonun artırılması sektörün geleceği açısından önemlidir. Buna göre bu çalışma daha önceden yapılan çalışmalara katkıda bulunmak, daha sonra bu konuda yapılacak çalışmalara rehberlik etmek ve turizm sektörüne bu konuda bilgi vererek mevcut uygulamaların geliştirilmesini sağlamak açısından önem arz etmektedir.

Araştırmanın, sadece Selçuk Üniversitesi Beyşehir Ali Akkanat Turizm Fakültesi ve MYO'daki Turizm ile ilgili bölümlerde okuyan öğrencilerine uygulanması, Türkiye genelinde tüm üniversitelerin tamamına ulaşmanın güç olması, çalışmanın zaman ve maliyet kıııları, verilerin anketi cevaplayan katılımcıların kişisel algılamalarına dayanması sebebiyle araştırma belirli sınırlılıkları taşımaktadır.

\subsection{Evren ve Örneklem}

Türkiye'de değişik düzeylerde turizm eğitimi veren kurumların varlığına rağmen, yetiştirilen öğrencilerin sayısındaki yetersizlikler ve yetiştirilen öğrenciler arasındaki nitelik farklılıkları irdelenmesi gereken önemli bir araştırma konusu olduğu düşünülmektedir. Türkiye'de örgün ve yaygın olmak üzere birçok eğitim kurumu sektöre yönelik kalifiyeli insan kaynağı yetiştirmektedir. Araştırma, Konya Selçuk Üniversitesi Beyşehir Ali Akkanat Turizm fakültesi ve MYO'da turizm üzerine eğitim gören öğrenciler üzerine yapılmıştır. Turizm fakültesinde 305, MYO'da ise (Aşçlıı, Turizm Otel İşletmeciliği, Turist rehberliği) turizm üzerine eğitim gören 210 öğrenci vardır. Eksiksiz doldurulan 215 anket kullanılarak analizleri yapılmıştır.

\subsection{Teorik Model, Hipotezler}

Bu çalışma "turizm öğrencilerinin umutsuzluk düzeyleri sektöre olan tutumlarını etkiler mi?" sorusuna cevap aramaktadır. Bu araştırma doğrultusunda turizm bölümünde okuyan öğrencilerin umutsuzluk düzeyleri ve sektörel tutumlarına yönelik aşağıdaki model hazırlanmıştır.

Şekil 1: Teorik Model
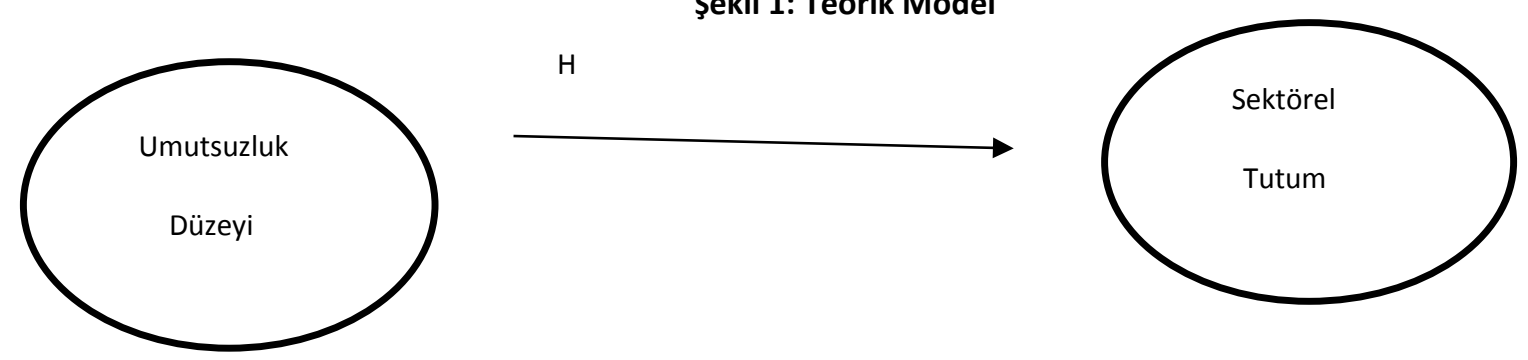

Bu doğrultuda araştırma soruları ve hazırlanan hipotezler aşağıdaki gibidir;

$H 1_{1}$ : Öğrencilerin umutsuzluk düzeylerinin turizm sektörüne tutumları üzerine anlamlı bir etkisi vardır.

$\mathrm{H} 2_{1}$ : Öğrencilerin turizm sektörüne karşı tutumlarında cinsiyete göre anlamlı bir farklıık vardır.

$\mathrm{H} 2_{2}$ : Öğrencilerin umutsuzluk düzeylerinde cinsiyete göre anlamlı bir farklılık vardır.

H3 $_{1}$ : Öğrencilerin imkânları olsa turizm okulu dışında bir okulda okumak isteyip istememelerine göre sektöre karşı tutumları farklılık göstermektedir.

$\mathrm{H3}_{2}$ : Öğrencilerin imkânları olsa turizm okulu dışında bir okulda okumak isteyip istememelerine göre umutsuzluk düzeyleri farklııık göstermektedir.

$\mathrm{H} 4_{1}$ : Öğrencilerin okudukları bölüme isteyerek gelip gelmemelerine göre sektöre karşı tutumları farklılık göstermektedir.

$\mathrm{H}_{2}$ : Öğrencilerin okudukları bölüme isteyerek gelip gelmemelerine göre umutsuzluk düzeyleri farklılık göstermektedir. 


\subsection{Verilerin Toplanma Yöntemi ve Ölçekler}

Veri toplama aracı olarak anket yönteminden yararlanılmıştır. Anketin birinci bölümünde üniversite öğrencilerinin kişisel bilgilerine ulaşmak adına, yaş, cinsiyet, okudukları bölüm, turizm bölümünü seçme nedenleri ve buna yönelik bilgileri elde etmeye yönelik sorular yer almaktadır.

Sektörel tutum ve kariyer seçimi ölçeğinin ilk bölümünde bulunan 39 madde sektörel tutuma yönelik ifadeleri içerirken son 10 madde kariyer seçimi ölçeğine ait ifadeleri içermektedir. Bu ölçek Duman, Tepeci ve Unur (2006) tarafından oluşturulmuştur. Bu ölçekte bulunan maddeler; 1=kesinlikle katılmıyorum ve 5=tamamen katılıyorum olmak üzere 5'li likert ölçeği ile değerlendirilmiştir.

Anketin üçüncü bölümünde Beck Umutsuzluk Ölçeği ile bireyin geleceğe yönelik karamsarlık derecesini belirlemek amaçlanmaktadır. Sorulara doğru-yanlış şeklinde cevap verilmekte ve ölçek sonuçları negatif beklentileri yansıtmaktadır. Bireyden kendisine uygun gelen ifadeler için "evet", uygun olmayanlar için "hayır" şıkkını seçmesi istenir. 1, 3, 5, 6,8, 10, 13, 15 , 19. sorularda "hayır"; 2, 4, 7, 9, 11, 12, 14, 16, 17, 18, 20. sorulara ise "evet" yanıtı için 1 puan verilir. Minimum puan 0 , maksimum puan 20' dir. Alınan puanlar yüksek olduğunda bireydeki umutsuzluğun yüksek olduğu varsayllır. Elde edilen toplam puan umutsuzluk puanı olarak kabul edilmektedir (Aktaran: Dinçer, 2013:36). Bu ölçek 2013 Dinçer (2013)'in yüksek lisans tezinden alınmıştır. Türkiye'de birçok çalışmada kullanılan umutsuzluk ölçeğinin güvenirliliği için Cronbach Alpha değeri 0,86 olarak hesaplanmıştır.

\section{BULGULAR VE TARTIŞMA}

\subsection{Demografik Bulgular}

Anketin birinci bölümünde yer alan demografik sorulara katılımcıların yanıtlarına göre frekans analizi uygulanmıştır. Analiz sonuçlarına göre katılımcıların \%74,4'ünün turizm fakültesi, \%25,6'sının MYO öğrencisi olduğu görülmektedir. Katılımcıların $\% 58,6$ 'sının kız, \%74,4'ünün Turizm işletmeciliği bölümünde okuduğu, \%46,1'inin 1.sınıf öğrencisi olduğu ve \%40,9'nun 20 ve üzeri yaşta olduğu sonuçlarına ulaşılmıştır.

Tablo 2: Demografik Bulgular; Cinsiyet, Yaş, Okul Bilgileri

\begin{tabular}{|c|c|c|c|}
\hline & & Frekans & Oran (\%) \\
\hline \multirow{2}{*}{ Okul } & Turizm Fakültesi & 160 & 74,4 \\
\hline & MYO & 55 & 25,6 \\
\hline \multirow[t]{2}{*}{ Cinsiyet } & Erkek & 126 & 58,6 \\
\hline & $\mathrm{K} / \mathrm{z}$ & 89 & 41,4 \\
\hline \multirow{3}{*}{ Bölüm } & Turizm İşletmeciliği & 160 & 74,4 \\
\hline & Turizm Rehberliği & 23 & 10,7 \\
\hline & Aşçılık & 32 & 14,9 \\
\hline \multirow{3}{*}{ Sinıf } & $1 . \sin ı f$ & 99 & 46,1 \\
\hline & 2.sinıf & 71 & 33 \\
\hline & 3.sinıf & 45 & 20,9 \\
\hline \multirow{4}{*}{ Yaş } & 18 & 23 & 10,7 \\
\hline & 19 & 38 & 17,7 \\
\hline & 20 & 66 & 30,7 \\
\hline & 20 ve üzeri & 88 & 40,9 \\
\hline Toplam & & 215 & $\% 100$ \\
\hline
\end{tabular}

Katılımcıların turizm eğitimi aldıkları bölümlerine yönelik yüzdelere baktığımızda, “Okuduğunuz bölümü isteyerek mi seçtiniz?” sorusuna \%55,4'ünün evet isteyerek seçtiğini, \%21,4'ünün başka seçeneğim yoktu seçeneğini, \%15,3'ünün hayır istemeyerek geldim cevabını verdiği görülmektedir. \%75,3'ünün "İmkânınız olsa turizm okulu dışında bir okulda okumak ister miydiniz?" sorusuna, evet isterdim yanıtını verdiği görülmüştür. "Mezun olunca çalışmak istediğiniz alan nedir?" sorusuna $\% 16,7$ 'sinin memur, $\% 16,3$ 'ünün kendi işini kurmayı düşündüğünü, \%14,4'ünün konaklama işletmelerinde çalışmayı düşündüğü sonucuna ulaşılmıştır. 
Tablo 3: Turizm Eğitimi Alınan Okula Yönelik Bilgiler

\begin{tabular}{|c|c|c|c|}
\hline & & Frekans & Oran (\%) \\
\hline \multirow{5}{*}{$\begin{array}{l}\text { Okuduğunuz bölümü } \\
\text { isteyerek mi seçtiniz? }\end{array}$} & Evet isteyerek & 119 & 55,4 \\
\hline & Ailemin İsteği ile & 14 & 6,5 \\
\hline & Hayır İstemeyerek & 33 & 15,3 \\
\hline & Başka Seçeneğim Yoktu & 46 & 21,4 \\
\hline & Diğer & 3 & 1,4 \\
\hline \multirow{2}{*}{$\begin{array}{l}\text { İmkânınız olsa turizm okulu } \\
\text { dışında bir okulda okumak } \\
\text { ister miydiniz? }\end{array}$} & Evet İsterdim & 162 & 75,3 \\
\hline & Hayır İstemezdim & 53 & 24,7 \\
\hline \multirow{10}{*}{$\begin{array}{l}\text { Mezun olunca çalışmak } \\
\text { istediğiniz alan nedir? }\end{array}$} & Konaklama işletmesi & 31 & 14,4 \\
\hline & Seyahat Acentesi & 16 & 7,4 \\
\hline & $\begin{array}{l}\text { Üniversite Öğretim } \\
\text { Elamanı }\end{array}$ & 58 & 27 \\
\hline & Havayolu Şirketleri & 11 & 5,1 \\
\hline & Restoran & 12 & 5,6 \\
\hline & Memur & 36 & 16,7 \\
\hline & $\begin{array}{l}\text { Kendi işyerimi kurmak } \\
\text { isterim }\end{array}$ & 35 & 16,3 \\
\hline & Aşçı & 2 & 0,9 \\
\hline & Diğer & 13 & 6 \\
\hline & Mutfak & 1 & 0,5 \\
\hline \multirow{4}{*}{$\begin{array}{l}\text { Mezun olunca çalışmak } \\
\text { istediğiniz kurum }\end{array}$} & Özel & 78 & 36,3 \\
\hline & Devlet & 82 & 38,1 \\
\hline & Üniversite & 52 & 24,2 \\
\hline & Diğer & 3 & 1,4 \\
\hline Toplam & & 215 & $\% 100$ \\
\hline
\end{tabular}

\subsection{Güvenilirlik Analizi}

Turizm bölümü öğrencilerinin sektöre karşı tutumlarını ölçme amacıyla hazırlanan sorulara verilen cevaplar sonucu yapılan güvenilirlik analizi sonucunda oluşan 49 ifadenin Cronbach's Alpha değeri \%83'4'dür. Bu da sektörel tutum ölçeğinin oldukça güvenilir bir ölçek olduğunu bize göstermektedir.

\subsection{Farklılık Testleri}

\subsubsection{Cinsiyete Göre Öğrencilerin Turizm Sektörüne Karşı Tutumları ve Umutsuzluk Düzeyleri Açısından Bağımsız Örneklem t Testi}

Birbirinden bağımsız 2 grubun veya örneklemin bağımlı bir değişkene göre ortalamalarının karşılaştırılarak ortalamalar arasındaki farkın belirli bir güven düzeyinde (\%95, \%99 gibi ) anlamlı olup olmadığını test etmek için kullanılan istatistiksel bir tekniktir (Ural , 2006,200).

Tablo 4'de, öğrencilerin turizm sektörüne karşı tutumları ve umutsuzluk düzeylerinde cinsiyete göre bir farklılığın olup olmadığını ölçmek üzere yapılan bağımsız örneklem t testi sonuçları yer almaktadır. Sonuçlara bakıldığında öğrencilerin turizm sektörüne karşı tutumlarında, kızlar ve erkekler arasında anlamlı bir farklııı olduğu sonucuna ulaşılmıştır $(p=0,04)$. Umutsuzluk konusunda ise cinsiyete göre bakış açılarında herhangi bir fark olmadığı sonucuna ulaşılmıştır $(p=0,23)$. Kızların ve erkeklerin genel anlamda umutsuzluk düzeyleri 1'e yakın yani yüksek çıkmıştır.

$$
\begin{aligned}
& \mathrm{H} 2_{1} \text { : Öğrencilerin turizm sektörüne karşı tutumlarında cinsiyete göre anlamlı bir farklılık vardır. } \\
& \mathrm{H} 2_{2} \text { : Öğrencilerin umutsuzluk düzeylerinde cinsiyete göre anlamlı bir farklılık vardır.. } \\
& \mathrm{H} 2_{1} \text { : Kabul edilir. } \\
& \mathrm{H} 2_{2} \text { : Reddedilir. }
\end{aligned}
$$


Tablo 4. Öğrencilerin Turizm Sektörüne Karşı Tutumları ve Umutsuzluk Düzeyleri Açısından Cinsiyetlerine Göre Bağımsız Örneklem Testi

\begin{tabular}{|l|l|r|r|r|r|r|}
\hline & Cinsiyet & \multicolumn{1}{|c|}{ Sayı } & Df & $\begin{array}{c}\text { t } \\
\text { Değeri }\end{array}$ & F & Sig. \\
\hline $\begin{array}{l}\text { Öğrencilerin Turizm } \\
\text { Sektörüne } \\
\text { Karşı } \\
\text { Tutumları/Cinsiyet }\end{array}$ & Erkek & 126 & 213 & $\begin{array}{l}-2,067 \\
-2,012\end{array}$ &, 087 &, 04 \\
\hline Umutsuzluk/Cinsiyet & Erkek & 126 & 213 & 1,191 & 5,873 &, 23 \\
\hline
\end{tabular}

\subsection{2. Öğrencilerin İmkânları Olsa Turizm Okulu Dışında Bir Okulda Okumak İsteyip İstememeleri ile Sektöre} Karşı Tutumları Ve Umutsuzluk Düzeyleri Açısından Bağımsız Örneklem t Testi

Aşağıdaki Tablo 5'de ankete katılan öğrencilerin imkânları olsa turizm okulu dışında bir okulda okumak isteyip istememeleri ile sektöre karşı tutumlarının ve umutsuzluk düzeylerinin farklılık gösterip göstermediğini araştırmak üzere Bağımsız Örneklem t testi yapılmıştır. İmkânım olsa turizm okulu dışında bir okulda okumayı evet isterdim, hayır istemezdim diyenler arasında turizm sektörüne bakış açısında farklılık olduğu, bu farklılığın anlamlı olduğu sonucuna ulaşılmıştır $(p<0,05)$.

İmkânım olsa turizm okulu dışında bir okulda okumayı evet isterdim, hayır istemezdim diyenler arasında umutsuzluk düzeyi açısından farklılık olmadığı sonucuna ulaşılmıştır ( $p>0,05)$.

H3 $_{1}$ : Öğrencilerin imkânları olsa turizm okulu dışında bir okulda okumak isteyip istememelerine göre sektöre karşı tutumları farklılık göstermektedir.

$\mathrm{H}_{2}$ : Öğrencilerin imkânları olsa turizm okulu dışında bir okulda okumak isteyip istememelerine göre umutsuzluk düzeyleri farklılık göstermektedir.

$$
\begin{aligned}
& \mathrm{H}_{3} \text { : Kabul edilir. } \\
& \mathrm{H}_{2} \text { : Reddedilir. }
\end{aligned}
$$

Tablo 5. Öğrencilerin İmkânları Olsa Turizm Okulu Dışında Bir Okulda Okumak İsteyip İstememelerine Göre

\begin{tabular}{|c|c|c|c|c|c|c|}
\hline & $\begin{array}{l}\text { İmkânı Olsa } \\
\text { Turizm Okulu } \\
\text { Dışında Bir Okulda } \\
\text { Okumayı İsteme } \\
\text { Durumu }\end{array}$ & Sayı & df & $\begin{array}{c}\mathbf{t} \\
\text { Değeri }\end{array}$ & $F$ & Sig. \\
\hline $\begin{array}{l}\text { Öğrencilerin Turizm } \\
\text { Sektörüne } \\
\text { Karşı Tutumları/ İmkânı olsa } \\
\text { turizm okulu dışında bir } \\
\text { okulda okumayı isteme } \\
\text { durumu }\end{array}$ & $\begin{array}{l}\text { Evet İsterdim } \\
\text { Hayır İstemezdim }\end{array}$ & $\begin{array}{r}163 \\
52\end{array}$ & $\begin{array}{r}213 \\
97,537\end{array}$ & $\begin{array}{l}4,136 \\
4,443\end{array}$ & ,518 & 00 \\
\hline $\begin{array}{l}\text { Umutsuzluk/ İmkânı olsa } \\
\text { turizm okulu dışında bir } \\
\text { okulda okumayı isteme } \\
\text { durumu }\end{array}$ & $\begin{array}{l}\text { Evet İsterdim } \\
\text { Hayır İstemezdim }\end{array}$ & $\begin{array}{r}162 \\
52\end{array}$ & $\begin{array}{l}212 \\
161,000\end{array}$ & $\begin{array}{l}, 566 \\
1,000\end{array}$ & 1,296 & ,57 \\
\hline
\end{tabular}
Sektöre Karşı Tutumları Ve Umutsuzluk Düzeyleri Açısından Bağımsız Örneklem t Testi 


\subsection{3.Öğrencilerin Okudukları Bölüme İsteyerek Gelip Gelmemeleri ile Sektöre Karşı Tutumları ve Umutsuzluk Durumları Arasındaki One-Way Anova Testi}

Aşağıdaki Tablo 6'da ankete katılan öğrencilerin okudukları bölüme isteyerek gelip gelmemeleri ile sektöre karşı tutumlarının ve umutsuzluk düzeylerinin farklılık gösterip göstermediğini araştırmak üzere Anova testi yapılmıştır. Turizm bölümüne evet isteyerek geldim, ailemin isteği ile geldim, hayır istemeyerek geldim ve başka seçeneğim yoktu diyenler arasında turizm sektörüne bakış açısında farklılık olduğu, bu farklıı̆ı̆ın anlamlı olduğu sonucuna ulaşıımıştır. p <0,05.

Turizm bölümüne evet isteyerek geldim, ailemin isteği ile geldim, hayır istemeyerek geldim ve başka seçeneğim yoktu diyenler arasında umutsuzluk düzeyi açısında farklılık olmadığı sonucuna ulaşılmıştır ( $p>0,05)$.

$\mathrm{H}_{1}$ : Öğrencilerin okudukları bölüme isteyerek gelip gelmemelerine göre sektöre karşı tutumları farklılık göstermektedir.

$\mathrm{H}_{2}$ : Öğrencilerin okudukları bölüme isteyerek gelip gelmemelerine göre umutsuzluk düzeyleri farklılık göstermektedir.

$$
\begin{aligned}
& \mathrm{H} 4_{1} \text { : Kabul edilir. } \\
& \mathrm{H} 4_{2} \text { : Reddedilir. }
\end{aligned}
$$

\begin{tabular}{|c|c|c|c|c|c|c|}
\hline & & Kareler Toplamı & df & $\begin{array}{c}\text { Kareler } \\
\text { Ortalaması }\end{array}$ & $\mathrm{F}$ & Sig. \\
\hline $\begin{array}{l}\text { Sektöre Karşı Tutum } \\
\text { ve Turizm Bölümüne } \\
\text { İsteyerek Gelip } \\
\text { Gelmeme Durumu }\end{array}$ & $\begin{array}{l}\text { Gruplar arası } \\
\text { Grup içi } \\
\text { Toplam }\end{array}$ & $\begin{array}{r}2,704 \\
33,679 \\
36,382\end{array}$ & $\begin{array}{c}4 \\
210 \\
214\end{array}$ & $\begin{array}{l}\text { 676 } \\
\text { 160 }\end{array}$ & 4,215 & ,003 \\
\hline \multirow{3}{*}{$\begin{array}{l}\text { Umutsuzluk ve } \\
\text { Turizm Bölümüne } \\
\text { İsteyerek Gelip } \\
\text { Gelmeme Durumu }\end{array}$} & Gruplar arası & 0,000 & 4 & ,000 & 912 & ,458 \\
\hline & Grup içi & 0,020 & 209 & ,000 & & \\
\hline & Toplam & 0,020 & 213 & & & \\
\hline
\end{tabular}

Tablo 6: Turizm Bölümüne İsteyerek Gelip Gelmeme Durumu ile Sektöre Karşı Tutum ve Umutsuzluk için Anova Testi

\subsection{Basit Doğrusal Regresyon Analizi}

Öğrencilerin umutsuzluk düzeyleri ile turizm sektörüne olan tutumları üzerindeki etkisini ortaya çıkarmak için regresyon analizi yapılmıştır.

\begin{tabular}{|c|c|c|c|c|c|}
\hline Model & $\mathrm{R}$ & R Square & Adjusted R Square & \multicolumn{2}{|c|}{ Std. Error of the Estimate } \\
\hline 1 &, $144^{\mathrm{a}}$ & ,021 & ,016 & \multicolumn{2}{|c|}{ 40579 } \\
\hline Model & $\begin{array}{l}\text { Sum of } \\
\text { Squares }\end{array}$ & $d f$ & Mean Square & $\mathrm{F}$ & Sig. \\
\hline $\begin{array}{l}\text { Regression } \\
\text { Residual } \\
\text { Total }\end{array}$ & $\begin{array}{c}, 740 \\
34,910 \\
35,650\end{array}$ & $\begin{array}{c}1 \\
212 \\
213\end{array}$ & $\begin{array}{l}\text { 740 } \\
\text {,165 }\end{array}$ & 4,492 &, $035^{\mathrm{a}}$ \\
\hline \multirow[t]{2}{*}{ Model } & \multicolumn{2}{|c|}{$\begin{array}{l}\text { Unstandardized } \\
\text { Coefficients }\end{array}$} & $\begin{array}{l}\text { Standardized } \\
\text { Coefficients }\end{array}$ & & \\
\hline & B & Std. Error & Beta & $\mathrm{t}$ & SIg. \\
\hline $\begin{array}{l}\text { (Constant) } \\
\text { Umutsuzluk }\end{array}$ & $\begin{array}{l}-2,651 \\
6,034\end{array}$ & $\begin{array}{l}2,849 \\
2,847\end{array}$ & 144, & $\begin{array}{l}-, 931 \\
2,119\end{array}$ & ,035 \\
\hline
\end{tabular}

\section{Tablo 7. Basit Doğrusal Regresyon Analizi}


Öğrencilerin Umutsuzluk düzeylerinin turizm sektörüne tutumları üzerine etkisini ortaya koymak üzere kurulan regresyon analizi anlamlıdır ( $F=4,492$ ve $p=0,035)$.

$$
\begin{aligned}
& H 1_{1}: H 1_{1} \text { : Öğrencilerin Umutsuzluk düzeylerinin turizm sektörüne tutumları üzerine anlamlı bir etkisi vardır. } \\
& \mathrm{H} 1_{1} \text { : Kabul edilir. }
\end{aligned}
$$

\section{SONUC}

Öğrencilerin turizm sektörüne karşı tutumları ve umutsuzluk düzeylerinde cinsiyete göre bir farklılığın olup olmadığını ölçmek üzere yapılan bağımsız örneklem $t$ testi sonuçları yer almaktadır. Sonuçlara bakıldığında öğrencilerin turizm sektörüne karşı tutumlarında, kızlar ve erkekler arasında anlamlı bir farklılık olduğu sonucuna ulaşılmıştır $(p=0,04)$. Umutsuzluk konusunda ise cinsiyete göre bakış açılarında herhangi bir fark olmadığı sonucuna ulaşılmıştır $(p=0,23)$. Kızların ve erkeklerin genel anlamda umutsuzluk düzeyleri 1'e yakın yani yüksek çıkmıştır.

Ankete katılan öğrencilerin imkânları olsa turizm okulu dışında bir okulda okumak isteyip istememeleri ile sektöre karşı tutumlarının ve umutsuzluk düzeylerinin farklılık gösterip göstermediğini araştırmak üzere Bağımsız Örneklem t testi yapılmıştır. İmkânım olsa turizm okulu dışında bir okulda okumayı evet isterdim, hayır istemezdim diyenler arasında turizm sektörüne bakış açısında farklılık olduğu, bu farklıı̆ın anlamlı olduğu sonucuna ulaşılmıştır $(p<0,05)$. İmkânım olsa turizm okulu dışında bir okulda okumayı evet isterdim, hayır istemezdim diyenler arasında umutsuzluk düzeyi açısından farklılık olmadığı sonucuna ulaşılmıştır ( $p>0,05)$.

Ankete katılan öğrencilerin okudukları bölüme isteyerek gelip gelmemeleri ile sektöre karşı tutumlarının ve umutsuzluk düzeylerinin farklılık gösterip göstermediğini araştırmak üzere Anova testi yapılmıştır. Turizm bölümüne evet isteyerek geldim, ailemin isteği ile geldim, hayır istemeyerek geldim ve başka seçeneğim yoktu diyenler arasında turizm sektörüne bakış açısında farklıık olduğu, bu farklılığın anlamlı olduğu sonucuna ulaşılmıştır. $p<0,05$. Turizm bölümüne evet isteyerek geldim, ailemin isteği ile geldim, hayır istemeyerek geldim ve başka seçeneğim yoktu diyenler arasında umutsuzluk düzeyi açısında farklılık olmadığı sonucuna ulaşılmıştır ( p>0,05).

Öğrencilerin umutsuzluk düzeylerinin turizm sektörüne tutumları üzerine etkisini ortaya koymak üzere kurulan regresyon analizi anlamlıdır ( $p=0,035)$. Bu da göstermektedir ki geleceğe umutsuzca bakan turizm öğrencileri muhtemel çalışacakları sektöre de olumlu gözle bakmamaktadırlar. Bu da birebir müşteriye hizmet sunan çalışanın yer aldığı sektörde çalışanların işinden tatmin olmaması, istek ve motivasyon ile görev icra etmemesi, eğitim hayatındaki bilgiler ile uygulamada ki farklılıkların işe olumsuz yansıması gibi durumların artışına neden olabilir. Bu yüzden daha eğitim aldığı okul sıralarında bölümü ile bilgi, staj, kaliteli eğitim süreçleri, kariyer basamakları gibi konularda öğrencinin daha fazla bilgilendirilmesi umutsuzluğa neden olan sektör ile alakalı bilgisizliğin giderilerek daha kalifiyeli çalışanların sektöre yetiştirilmesi ülke ekonomisi açısından da hayati önem taşımaktadır. Türkiye'ye daha kaliteli turist çekmek için turizm eğitiminin önemi ve bu konu ile alakalı çözüm yöntemleri geliştirilmelidir. Sektörde müşteri ile yüz yüze hizmet sunan çalışanların hizmet kalitesi artıkça, hizmeti tekrar tercih etmeye gönüllü müşteri sayısı da artacaktır. Bu sebeple turizm sektöründe bir marka haline gelebilmenin temel şartı hizmetin kalitesine ve bu hizmeti sunan çalışanın motivasyonuna bağlı olduğu unutulmamalıdır.

\section{KAYNAKLAR}

Aras, A., (2011), Müzik Bölümü Lisans Öğrencilerinin Umutsuzluk Düzeylerinin Belirlenmesi: Hacettepe Üniversitesi Ankara Devlet Konservatuarı Örneği, Gazi Eğitim Fakültesi Dergisi, Cilt, 31, Sayı 2, 509-524.

Ayaz, N., Yeşiltaş, M., Türkmen, F., (2012), Turizm Eğitimi Alan Öğrencilerin Kırsal Turizme Bakış Açıları ve Algıları Üzerine Bir Araştırma, KMÜ Sosyal ve Ekonomik Araştırmalar Dergisi 14 22, 103-112.

Baş, A. U., Kabasakal, Z., (2013), Öğretmen Adaylarında Umutsuzluk Ve Algılanan Sosyal Destek, Eğitim ve Öğretim Araştırmaları Dergisi, Şubat, Cilt:2, Sayı:1, ISSN:2146-9199, 19-26

Bayer, E. (1998), Türkiye Meslek Yüksekokulları Turizm Eğitimi Kalitesinin Geliştirilmesinde Sanal Yöntemlerin Rolü, Süleyman Demirel Üniversitesi, İktisadi Ve İdari Bilimler Fakültesi Dergisi, Sayı: 3: 145-156.

Boylu, E., Arslan, E., (2014), Türkiye'deki Turizm Eğitiminin Rakamsal Gelişmeler AçısındanDeğerlendirilmesi, Gazi Üniversitesi Turizm Fakültesi Dergisi, Sayı:1 , 79-97.

Duman, T., Tepeci, M. Unur, K., (2006) “Mersin'de Yüksekögretim ve Orta Ögretim Düzeyinde Turizm Egitimi Almakta Olan Ögrencilerin Sektörün Çalısma Kosullarını Algılamaları ve Sektörde Çalısma İsteklerinin Karsılastırmalı Analizi”. Anatolia:Turizm Arastırmaları Dergisi, c.17, s.1, ss.51-69.

Ehtiyar, R., Üngüren, E., (2008), Turizm Eğitimi Alan Öğrencilerin Umutsuzluk Ve Kaygı Seviyeleri 
Ile Eğitime Yönelik Tutumları Arasındaki Illişkinin Belirlenmesine Yönelik Bir Araştırma, Uluslararsı Sosyal Araştırmalar Dergisi, Vol:1-4, 159181.

Ilgaz, B., (2011), Üniversite Düzeyinde Turizm Eğitimi Alan Öğrencilerinin Yılmazlık, Umutsuzluk Durumları Ve Sektörel Tutumlarının Kariyer Seçimlerine Etkileri: Akdeniz Üniversitesi Örneği, Yüksek Lisans Tezi, Akdeniz Üniversitesi, Sosyal Bilimler Enstitüsü, Turizm İşletmeciliği ve Otelcilik Ana Bilim Dalı.

İmamoğlu, A., Yavuz, A., (2011), Üniversite Gençliğinde Dini İnanç ve Umutsuzluk, SakaryaÜniversitesi Illahiyat Fakültesi Dergisi, Cilt:XIII, Sayı: $23(2011 / 1), 205-244$

Kargın, M., Ünal, S., (2011), İnfertil Bireylerde Umutsuzluğun Belirlenmesi, New/Yeni Symposium Journal, Ocak, Cilt:49, Sayı:1, 54-60.

Kemer, G., ve Atik, K., (2005). Kırsal Ve II Merkezinde Yaşayan Lise Öğrencilerinin Umut Düzeylerinin Aileden Algılanan Sosyal Destek Düzeyine Göre Karşılaştırılması. Marmara Üniversitesi Atatürk Eğitim Fakültesi Eğitim Bilimleri Dergisi Sayı 21, 161-168.

Orhan, A., (2015), Türkiye'de Lisans Düzeyinde Turizm Eğitimi Alan Öğrencilerin Turizm Sektörü ille Ilgili Algılarının Çalışma Niyetleri Üzerindeki Etkisinin Belirlenmesi, Yüksek Lisans Tezi, Eskişehir Osman Gazi Üniversitesi, Sosyal Bilimler Enstitüsü, Turizm İşletmeciliği Anabilim Dalı, Eskişehir.

Özmen, D., Dündar, P.E., Çetinkaya, A.Ç., Taşkın, O. ve Özmen, E. (2008), Lise Öğrencilerinde Umutsuzluk ve Umutsuzluk Düzeyini Etkileyen Etkenler, Anadolu Psikiyatri Dergisi. Sayı : 1.

Tercanlı, N., Demir, V., (2012), Beck Umutsuzluk Ölçeğinin Çeșitli Değișkenler Açısından Değerlendirilmesi Gümüşhane illi Örneği, Gümüşhane Üniversitesi Sağlık Bilimleri Dergisi, 2012;1(1).

Üngüren, E., Ehtiyar, R., (2009), Türk Ve Alman Öğrencilerin Umutsuzluk Düzeylerinin Karşılaştırılması Ve Umutsuzluk Düzeylerini Etkileyen Faktörlerin Belirlenmesi: Turizm Eğitimi Alan Öğrenciler Üzerinde Bir Araştırma, Journal of Yaşar Universty, 4(14), 20932127.

Ural A. , Kılıç I., (2006). Bilimsel Araştırma Süreci ve SPSS ile Veri Analizi.(2.Baskı).Ankara : Detay Anatolia Akademik Yayıncılık Ltd. Şti.

Yağcı, Ö., (2001), Türkiye'de Turizm _istihdamında Karşılaşılan Temel Sorunlar Ve Çözüm Önerileri” Ticaret ve Turizm Eğitim Fakültesi Dergisi, Sayı 4, 2001, 23-39. 